\title{
A new species of Urostreptus (Diplopoda, Spirostreptidae): description and chromossome number
}

\author{
Pedro H. B. Pierozzi \& Carmem S. Fontanetti
}

Departamento de Biologia, Instituto de Biociências, Universidade Estadual Paulista Júlio de Mesquita Filho (UNESP), Avenida 24-A, 1515, 13506-900 Rio Claro, SP, Brasil. (fontanet@ rc.unesp.br)

\begin{abstract}
This work presents the description and chromosome number of Urostreptus atrobrunneus sp. nov. The genus until now had not been registered yet in the São Paulo State, Brazil. The meiotic analysis showed that the species presents $2 \mathrm{n}=24$, XY. The C-banding revealed large blocks of constitutive heterochromatin and two heteromorphic chromosomal pairs, one of them corresponding to the sexual pair.
\end{abstract}

KEYWORDS. Urostreptus, Diplopoda, cytogenetics, banding.

RESUMO. Uma nova espécie de Urostreptus (Diplopoda, Spirostreptidae): descrição e número cromossômico. O trabalho traz a descrição e o número cromossômico de Urostreptus atrobrunneus sp. nov. O gênero até o momento não havia sido registrado para o Estado de São Paulo, Brasil. A análise meiótica demonstrou que a espécie apresenta 2n=24, XY. O bandamento C revelou grandes blocos de heterocromatina constitutiva e dois pares de cromossomos heteromórficos, um deles correspondendo ao par sexual.

PALAVRAS-CHAVE. Urostreptus, Diplopoda, citogenética, bandeamento.

Urostreptus Silvestri, 1895 belongs to Spirostreptidae, being distributed throughout South America and characterized for presenting a median prominent carina on the epiproctum. These animals have an average size and a thin body.

The genus, described by Silvestri (1895) is composed by 12 species: $U$. borellii (Silvestri, 1895); $U$. camerani (Silvestri, 1895); U. cultratus (Humbert \& De Saussure, 1870); U. mineri (Chamberlin, 1941); $U$. tampiitauensis (Schubart, 1947); U. carvalhoi (Schubart, 1947); U. robustus (Verhoeff, 1951); U. munducurensis (Schubart, 1957); U. travassoi (Schubart, 1957); U. paxillatus Hoffman, 1968; U. auritus Hoffman, 1980 e $U$. fallax Hoffman, 1980.

Six species of Urostreptus have been reported in Brazil, with their distribution concentrated at the central States and, according to HofFMAN (1980), their absence at the eastern and southeastern parts of the country is noteworthy.

This work presents the description and chromosomal number of a new species of Urostreptus, widely distributed throughout the São Paulo State, southeastern Brazil.

\section{MATERIAL AND METHODS}

The specimens were collected at different sites in the São Paulo State and in different seasons of the year. For the cytogenetical analysis, the specimens were collected at the counties of Rio Claro (22 23 '59' S;

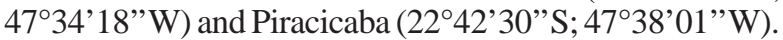

For chromosomal analysis, individuals were starved for one week and then injected with colchicine $0.08 \%$. After approximately 16 hours (overnight), the specimens were anesthetized and dissected in physiological solution. For the meiotical analysis, the testes were brought to the hypotonic state by incubation in tap water for five minutes, then fixed in Carnoy I and crushed in $45 \%$ acetic acid. The material was stained in 3\% Giemsa and subjected to C-banding, according to SuMNER (1972), with slight modifications.

The holotype was deposited in the collection of the Zoology Museum of the University of São Paulo (MZSP), SP, Brazil and paratypes in the collection of the Biology Department, Biosciences Institute (IBRC), São Paulo State University (UNESP), Rio Claro, SP, Brazil.

\section{RESULTS AND DISCUSSION}

\section{Urostreptus atrobrunneus sp. nov. (Figs. 1-8)}

Type material. Holotype đ', BRAZIL, São Paulo: Rio Claro (Fausto Santomauro highway, km 3 North), I.1984, R. Christofoletti col. (MZSP). Paratypes: BRAZIL, São Paulo: Rio Claro, 2 హ, 3 \&, I.1989, E. Giannotti col. (IBRC); 2 J', 2 \&, I.1996, R. Christofoletti col. (IBRC); ơ, III.1997, M. C. de Almeida col. (IBRC); (Fausto Santomauro highway, km 3 North), 2 \&, I.1984, R. Christofoletti col.; same locality, 8 O', 6 F, II.2002, A. Mesa \& C. B. Portugal col. (IBRC); (Washington Luis highway, km 177.3 North),1 immature, 4 ơ, 5 \&, I.1989, R. Christofoletti col. (IBRC); Paulínia: 3 o, , , II.1995, L. Boccardo col. (IBRC).

Description. Small species, with a mean of $50 \mathrm{~mm}$ in length, $3 \mathrm{~mm}$ in diameter and 46 segments; color dark brown with a lighter prozona, totally covered by metazona; dark brown head, collum, telson and antennae. Collum marked laterally by one groove. Epiproct slightly projected over paraprocts.

First pair of male legs. Strait coxa and divergent prefemural processes, orally projected.

Gonopods (Figs. 1,2). Coxite with about half-length of telocoxite. Telocoxite enlarged at the distal portion and guided towards the inside. Paragonocel long, 
prominent, covered with bristles, distal margin oblique. Telopodite free, long, narrow, directed caudad, tapering final portion only. Prefemural processes C-shaped.

Discussion. Urostreptus atrobrunneus sp. nov. is similar to $U$. borelli, which was described from Paraguay and Argentina (SILVESTRI, 1895; HoFFMAN, 1974, 1980) by the gonopods morphology, but Urostreptus atrobrunneus sp. nov. is smaller and probably the smallest species of the genus. It is agile, commonly found in buildings, underneath the masonry of house structures causing infestations, or in migratory groups. With relation to other species, the configuration of the gonopods is different, mainly the morphology of telocoxite.

Cytogenetical analysis. The species presents $2 n=24$ and a sexual determination system of the type XY in the males. The bivalent chromosomes appear close together and in some nuclei we observed the typical aspect of chromosomal chains formed by associations of chromatin (arrows in Figs. 3, 4). This fact is probably due to the high amount of heterochromatin found in this species.

The meiotic analysis revealed two heteromorphic pairs, one of them presents a slight size difference between the homologues and was identified as the sexual pair (Figs. 5, 7). The heteromorphism was highly evident with regards to their C-banding patterns (Figs. 6, 8). One of the chromosomes of the sexual pair was marked by a large $\mathrm{C}+$ block (the $\mathrm{X}$ chromosome) whereas the other had a much smaller block (Y chromosome) (Figs. 6, 8). The other bivalent pair presents a chromosome marked by a large $\mathrm{C}+$ block while the other chromosome had no apparent marks (arrows in Figs. 6, 8).

The Urostrepus species here analyzed was the first of the genus that has been studied from the cytogenetical point of view, which hampers a comparison of the results obtained. Members of the Spirostreptidae have been poorly studied cytogenetically, comprising a total of six species (ChOWDAiah \& KanAKa, 1969; Achar \& Chowdaiah, 1979, 1980; ACHAR 1983; Fontanetti, 1991, 1998 ) and none of them presents the diploid number found in Urostrepus atrobrunneus, sp. nov. Nevertheless, this number has already been observed in other millipedes belonging to different families (FONTANETTI et al., 2002).

The XY sex determination system observed in the males is the most frequent in millipedes. While studying Spirostrepus asthenes, AcHAR (1983) commented that the sex determination mechanism in the Diplopoda is in a primitive stage, since in most species the sexual pairs are poorly differentiated from the autosomes and, even between the $\mathrm{X}$ and $\mathrm{Y}$ chromosomes, the differences are very slight. Such a discrete sexual differentiation was clearly apparent in the species here presented; the heteromorphism of the sexual pair was thin when compared to the other chromosomes, and even between $\mathrm{X}$ and $\mathrm{Y}$, the difference is subtle.

The large amount of constitutive heterochromatin found in Urostrepus atrobrunneus sp. nov. was also observed in other species of diplopods both in Brazilian fauna and in representatives of other regions. Acanthopetalum sicanum (Berlese, 1883) (Callipodida) presents about 60 and $56 \%$ of heterochromatin, respectively in males and females and Enologus oxypygum (Julida) about $67 \%$, with this value being equal in males and females (VitTURi et al., 1997, 2001). The Brazilian species Pseudonannolene tocaiensis Fontanetti, 1996, P. silvestris Schubart, 1944 and $P$. strinatii Mauriès, 1974 also present a large amount of constitutive heterochromatin, representing in the later about $65 \%$ of the genome (CAMPOS \& FonTANETTI, 2004; SouZA et al., 2005).

The differential staining between the homologues, with regards to the constitutive heterochromatin, has been reported by several authors. KING (1991) also observed the same phenomenon on amphibians and, according to this author, these pairs are heteromorphic due to an addition of heterochromatin to one of the elements of the pair.

In a given species, homologous chromosomes might differ not only in the number and location of the C-bands (qualitative difference) but also on the amount of heterochromatin in any given C-band (quantitative difference). The detection of both types of differences in the types of C-bands (qualitative and quantitative) depends on different factors, such as the extent of the variation and/or degree of chromosomal condensation. Since a measure of the amount of heterochromatin in a specific band is difficult to acquire and given that chromosomal contractions might lead to the apparent fusion of neighboring C-bands, only large differences can be detected by this method, resulting in inexact estimations of the C-band models (SANTOS \& GIRÁLDEZ, 1982).

Although still rare in millipedes, the C-banding method has been applied in several animal species and it has rendered important clues regarding the evolutionary changes of the groups. The meaning of the heterochromatic fraction is one of the key points of current cytogenetical analyses (GUERRA, 1988).

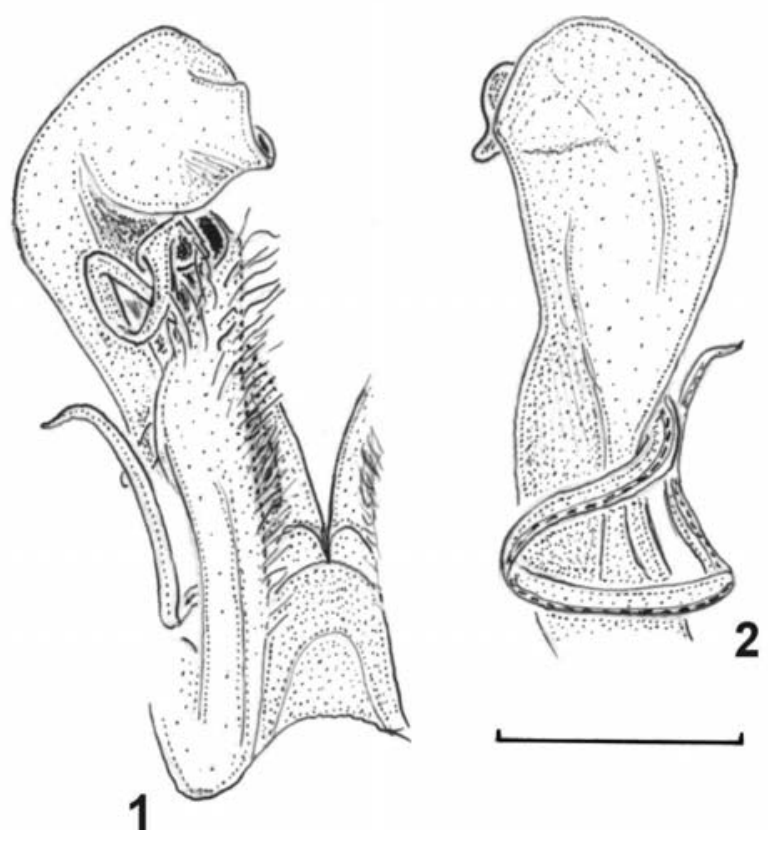

Figs. 1, 2. Gonopods of Urostreptus atrobrunneus sp. nov.: 1, oral view; 2, caudal view. $\mathrm{Bar}=1 \mathrm{~mm}$. 


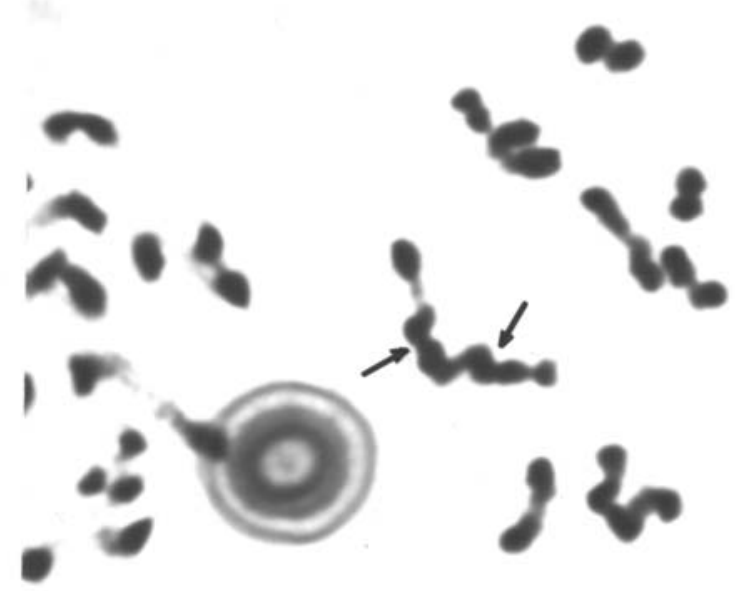

3

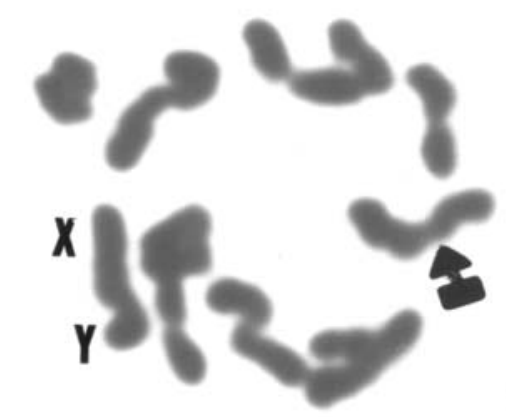

5
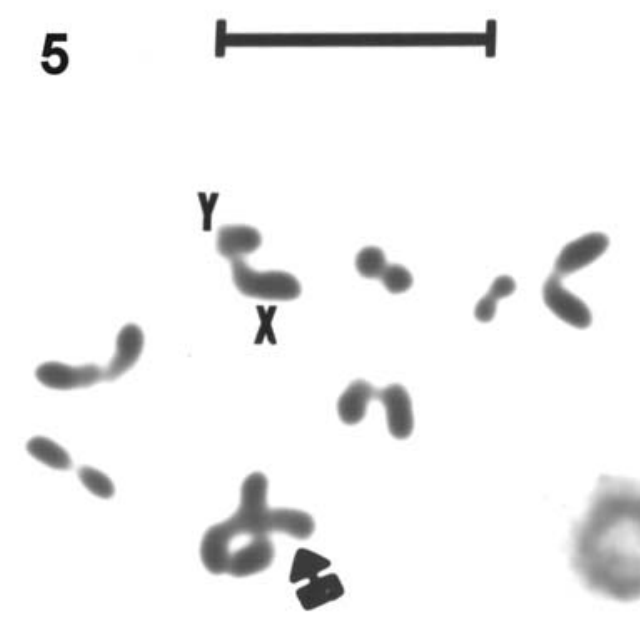

7

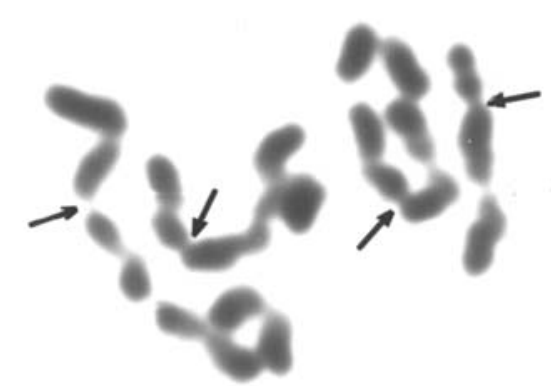

4
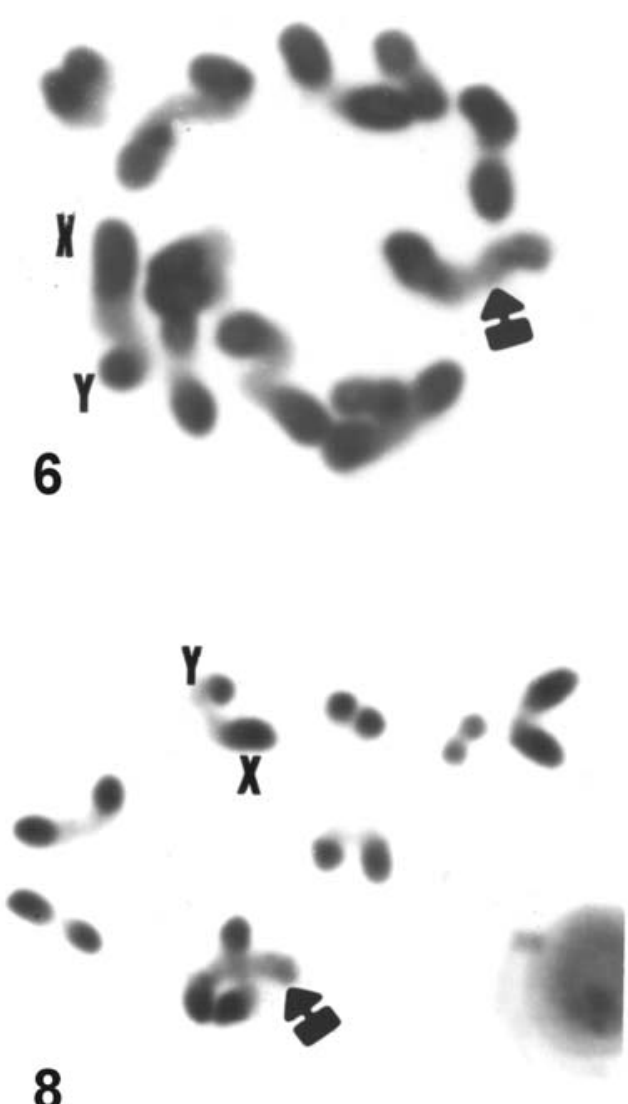

Figs. 3-8. Meiosis of Urostreptus atrobrunneus sp. nov.: 3-5, 7, staining with Giemsa. 6, 8, C-banding technique. Arrows in 3, 4 = associations between chromosomes; arrows in 5-8 $=$ heteromorphic pair; $\mathrm{X}, \mathrm{Y}=$ sexual pair. Bar $=10 \mu \mathrm{m}$.

Uncountable functions have been attributed to constitutive heterochromatin, including the protection of euchromatic regions (Hsu, 1975). However, the main functions credited to heterochromatin are the determination of the threedimensional structure of the interphase nucleus and its possible effect, direct or indirect, on gene expression (Hilliker \& ApPELs, 1980). In millipedes, several other studies will be needed in order to understand the role of constitutive heterochromatin in the karyotype, since most of the species studied up to now present over $50 \%$ of their genome composed of this type of chromatin.

Acknowledgments. We thank Reinor Christofoletti, for the discovery of the species, Cauré B. Portugal, Alejo Mesa, Edilberto Giannotti and Lilian Boccardo, for the collected exemplars, to the Dr. Sergei Golovatch (Russian Academy of Sciences), for the drawings, to the Dr. Richard Hoffman (Virginia Museum of Natural History), for the incentive in the description and to FUNDUNESP and PIBIC (CNPq), for the financial support. 


\section{REFERENCES}

AchAR, K. P. 1983. Karyological studies in nine species of Indian Diplopoda (Myriapoda). Nucleus 26(3):191-197.

Achar, K. P. \& Chowdaiah, B. N. 1979. The use of air drying in the study of diplopod chromosomes. In: Camatini, M. ed. Myriapod Biology. London, Academic. p.21-23.

1980. The use of C-banding technique in the chromosome studies of a millipede species Carlogonus acifer. Caryologia 33(2): $185-191$

Campos, K. A. \& Fontanetti, C. S. 2004. Chromosomal characterization of Pseudonannolene strinatii (Spirostreptida, Pseudonannolenidae). Iheringia, Série Zoologia, 94(1): 53-56.

Chowdaiah, B. N. \& Kanaka, R. 1969. Cytological studies of Indian Diplopoda. II. (Myriapoda). Bulletin du Muséum National d'Histoire Naturelle, Série 2, 41(2):43-47.

FontanetTi, C. S. 1991. Karyotype of some brazilian diplopods. Revista Brasileira de Genética 14(3):645-651. 1998. Chromosome numbers of some brazilian species of diplopods (Diplopoda, Arthropoda). Cytologia 63:149-154.

Fontanetti, C. S.; Campos, K. A.; Prado, R. A. \& Souza, T. S. 2002 Cytogenetic studies in Diplopoda. Cytologia 67:253-260.

Guerra, M. S. 1988. Introdução à citogenética geral. Rio de Janeiro, Guanabara Koogan. 142p.

Hilliker, A. J. \& Appels, R. 1980. The genetic analysis of D. melanogaster heterochromatin. Cell 21:607-619.

Hoffman, R. L. 1974. Studies on Spirostreptoid millipeds. XIII. Supplementary notes on the genus Urostreptus. Studies on the Neotropical Fauna 9:77-83.

1980. Studies on spirostreptoid millipeds. XVII. A third contribution to the knowledge of the genus Urostreptus
Silvestri, 1897. Papéis Avulsos de Zoologia 33(16): 263-274.

Hsu, T. C. 1975. A possible function of constitutive heterochromatin (C-bands) during eukaryotic chromosomal evolution and their cytological meaning. Japanese Journal of Genetics 66:635-661.

KING, M. 1991. The evolution of heterochromatin in the amphibian genome. In: Green, D. M. \& Sessions, S. K. eds. Amphibian Cytogenetics and Evolution. London, Academic. p.359-391.

Santos, J. L. \& Giráldez, R. 1982. C-heterochromatin polymorphism and variation in chiasm localization in Euchorthippus pulvinatus gallicus (Acrididae, Orthoptera). Chromosoma 85:507-518.

Silvestri, F. 1895. Viaggio del dottor Alfredo Borelli nella Republica Argentina e nel Paraguay. XIV. Chilopodi e Diplopodi. Bollettino dei Musei di Zoologia ed Anatomia Comparata 10(203):1-12.

Souza, T. S.; Prado, R. A. \& Fontanetti, C. S. 2005. High content of constitutive heterochromatin in two species of Pseudonannolene (Diplopoda). Caryologia 58(1):47-51.

Sumner, A. T. 1972. A simple technique for demonstrating centromeric heterochromatin. Experimental Cell Research 75:304-306.

Vitturi, R.; Colomba, M. S.; Caputo, V.; Sparacio, I. \& Barbieri, R. 1997. High heterochromatin content in somatic chromosomes of two unrelated species of Diplopoda (Myriapoda). Chromosome Research 5:407-412.

Vitturi, R.; Colomba, M. S.; Mandrioli, M.; Pirrone, A. M.; Grispo, G. \& BARBIERI, R. 2001. 18S-28S rDNA is interspersed throughout heterochromatin in the millipede Enologus oxypygum (Diplopoda). Genetica 110(2):151-155. 